\title{
COLLECTIVE LABOUR RIGHTS OF SELF-EMPLOYED PERSONS ON THE EXAMPLE OF SPAIN: IS THERE ANY LESSON FOR POLAND? ${ }^{1}$
}

\begin{abstract}
This paper aims to analyse collective labour rights of both "classic" selfemployed persons and economically dependent self-employed workers under the Spanish Statute of Self-Employed Workers (Ley 20/2007 del Estatuto del Trabajo Autónomo). The author applies comparative analysis and critical reasoning with a view to answering the questions: is the scope of protection wide enough, and can Poland draw a lesson from it? The paper presents evidence that demonstrates that among all self-employed workers, only economically dependent self-employed workers are granted the right to bargain collectively. However, findings suggest that in practice, collective bargaining is stymied mainly because it takes place only at the enterprise level, and because the number of economically dependent self-employed workers is minimal. The paper concludes that collective labour rights under the Statute of Self-Employed Workers could be better protected (especially as regards "classic" self-employed persons). On the other hand, however, in Poland, the lack of any criteria that would enable a diversification of the scope of collective rights granted to self-employed persons is subject to criticism. It appears that in some areas the legislator should differentiate the scope of protection. The criterion of economic dependence, which exists in Spanish law, could be successfully used for this purpose.
\end{abstract}

Keywords: self-employment, collective labour rights, Spanish law, "classic" self-employed persons, economically dependent self-employed workers.

\section{ZBIOROWE PRAWA PRACOWNICZE OSÓB SAMOZATRUDNIONYCH NA PRZYKLADZIE HISZPANII: LEKCJA DLA POLSKI?}

Streszczenie. Celem artykułu jest analiza zbiorowych praw pracowniczych zarówno „klasycznych” samozatrudnionych, jak i samozatrudnionych ekonomicznie zależnych w świetle hiszpańskiej ustawy Prawo samozatrudnionych (Ley 20/2007 del Estatuto del Trabajo Autónomo). Autorka posługuje się metodą porównawczą i wykorzystuje krytyczne rozumowanie, aby odpowiedzieć na pytania: czy zakres ochrony jest dostatecznie szeroki i czy Polska może wyciągnąć wnioski zuregulowań hiszpańskich. W artykule wskazano, że spośród wszystkich samozatrudnionych tylko osoby samozatrudnione ekonomicznie zależne mają prawo do rokowań zbiorowych. Wyniki

* University of Lodz, Faculty of Law and Administration, Department of European, International and Collective Labour Law; atyc@wpia.uni.lodz.pl

${ }^{1}$ The project was financed by the National Science Centre in Poland pursuant to the decision number DEC-2018/29/B/HS5/02534. The project's registration number is: 2018/29/B/HS5/02534. 
sugerują jednak, że w praktyce negocjacje zbiorowe są trudne, głównie dlatego, że odbywają się one wyłącznie na poziomie przedsiębiorstwa oraz ponieważ liczba pracowników samozatrudnionych ekonomicznie zależnych jest znikoma. W artykule podniesiono, że zbiorowe prawa pracownicze wynikające z Prawa samozatrudnionych mogłyby być lepiej chronione (zwłaszcza w odniesieniu do „klasycznych” samozatrudnionych). Z drugiej strony w Polsce krytykuje się brak jakichkolwiek kryteriów, które pozwalałyby na zróżnicowanie zakresu praw zbiorowych przysługujących osobom prowadzącym działalność na własny rachunek. Wydaje się, że w niektórych obszarach ustawodawca powinien zróżnicować zakres ochrony. W tym celu z powodzeniem można zastosować kryterium zależności ekonomicznej, które istnieje w prawie hiszpańskim.

Słowa kluczowe: samozatrudnienie, zbiorowe prawa pracownicze, prawo hiszpańskie, osoby „klasyczne” samozatrudnione, samozatrudnieni ekonomicznie zależni.

\section{INTRODUCTION}

According to available Eurostat data, in the first quarter of 2020 the number of self-employed people in Spain amounted to 2,927.1, ${ }^{2}$ and in light of the data for the whole 2019 that figure was $2,916.2^{3}$ out of 20,230.78 totally employed persons. ${ }^{4}$ The COVID-19 pandemic, which can be regarded as a black swan, has triggered a profound recession on a worldwide scale and has also influenced the situation of the self-employed in the county under analysis. Similarly to the situation caused by the global financial and economic crisis of 2008 (Ginès i Fabrellas 2020, 63, 80-81), we can expect that the coronavirus crisis may trigger further actions aiming at promoting self-employment in order to reduce the unemployment rate. This is only one of the reasons why the situation of the above-mentioned group of people should be carefully monitored. Another reason is related to fact that Spain adopted a separate statute for them, namely the Statute of Self-Employed Workers (Ley 20/2007, de 11 julio, del Estatuto del Trabajo Autónomo, ${ }^{5}$ LETA).

The objective of this paper is to critically assess collective labour rights of both "classic" self-employed persons and economically dependent self-employed workers (trabajadores autónomos económicamente dependientes) under the Spanish Statute of Self-Employed Workers (Ley 20/2007 del Estatuto del Trabajo Autónomo), and to answer the question whether the Polish legislator can draw a lesson from Spanish regulations.

Before scrutinising it closer, we shall pay attention to definitions established by LETA. It indicates the way in which a self-employed person should conduct an economic or professional activity in order to be included within its scope.

\footnotetext{
${ }^{2}$ https://appsso.eurostat.ec.europa.eu/nui/show.do?dataset=lfsq_esgais\&lang=en [Last update: 11 June 2020].

${ }^{3}$ https://appsso.eurostat.ec.europa.eu/nui/submitViewTableAction.do.

${ }^{4} \mathrm{https} / /$ ec.europa.eu/eurostat/databrowser/view/tec00112/default/table?lang=en (data based on the domestic concept).

${ }^{5}$ Boletín Oficial del Estado, 12 July 2007, no. 166.
} 
Article 1.1 LETA sets out that LETA shall apply to natural persons who perform an economic or professional activity for profit, regularly, personally, directly, on their own account and outside the sphere of management and organisation of another person, regardless of whether they employ employees (more: Apilluelo Martín 2018, 41 et seq.). As signalled above, LETA has also introduced a category of the economically dependent self-employed worker, which is defined as a worker performing an economic or professional activity for profit, regularly, personally, directly, and predominantly for an individual or legal person called a client, on whom he/she depends economically, receiving from such client at least 75 per cent of total income deriving from his/her economic and professional activities (Article 11.1 LETA). It should be noted that the economically dependent self-employed workers have been offered separate privileges by the Spanish legislator, e.g. the right to collective bargaining, and separate provisions regarding, among others, the so-called professional interests agreements. In addition to these regulations, they also enjoy rights arising from the so-called "Joint regime" provided for both "classic" self-employed persons and economically dependent self-employed workers.

\section{THE COLLECTIVE LABOUR RIGHTS OF SELF-EMPLOYED PERSONS: JOINT REGIME}

As regards professional and collective rights of self-employed persons under the "Joint regime", Article 19 LETA concerns fundamental collective rights (derechos colectivos básicos) granted to self-employed persons (more: Pérez Agulla 2016, 80 et seq.), grouped from the perspective of individual rights (interests) - paragraph 1; and collective rights (interests) - paragraph 2. The latter group includes collective rights granted to associations of self-employed persons, e.g. establishing a federation, confederation or trade union. By contrast, to the former group the Spanish legislator has qualified:

- the right to join a selected trade union or business association under the conditions set out in the relevant provisions,

- the right to join and form - without prior authorisation - specific professional associations of self-employed persons (asociaciones profesionales especificas de trabajadores autónomos),

- the right to take collective action to defend their professional interests.

However, it should be noted that Article 3.1 of the Organic Law on Trade Union Freedom (Ley Orgánica 11/1985, de 2 de agosto, de Libertad Sindical $)^{6}$ stipulates that self-employed workers who do not have workers at their service may join trade union organisations, but cannot found unions whose goal is to protect their singular interests, without prejudice to their ability to form associations under specific legislation.

${ }^{6}$ Boletín Oficial del Estado, 8 August 1985, no. 189. 
According to the data presented by A. Martín-Artiles, A. Godino and O. Molina (2019, 120-121), the most representative organisations of self-employees in 2016 were the Asociación de trabajadores autónomos (ATA), the Unión de Profesionales y Trabajadores Autónomos (UPTA), the Unión de Asociaciones de Trabajadores Autónomos y Emprendedores (UATAE), and the Confederación Intersectoral de Autónomos del Estado Español (CIAE) with 58.48 per cent, 22.04 per cent, 13.41 per cent and 6.07 per cent, respectively. This data reflects a significant increase (which has taken place since the 2000s) in the number of organisations representing self-employed persons. However, as pointed out by the authors, the trade union membership rate of the self-employed was only 6.9 per cent which was below the avarage for all employed workers in the economy, i.e. 16.4 per cent in 2010, when the latest data are available.

As regards the right to take collective action to defend self-employed persons' professional interests, it has been pointed out in the literature that "this collective activity to defend their interests does not come from the fundamental right to freedom of association, but from the private or common associationism of Article 22 of the Spanish Constitution, which will limit the possible actions in this collective dispute" (Todolí-Signes 2019, 260).

A lack of the business counterpart made the Spanish Constitutional Court (judgement 11/1981 of 8 April) issue a ruling according to which the right to strike being recognised in Article 28.2 of the Spanish Constitution ${ }^{7}$ is denied to selfemployed workers (Moreno Vida 2017, 646). In Spain there is still no regulation in force which would extend the right to strike to "classic" self-employed persons.

\section{THE COLLECTIVE LABOUR RIGHTS OF ECONOMICALLY DEPENDENT SELF-EMPLOYED WORKERS}

As indicated above, LETA gives economically dependent self-employed workers the possibility of becoming members of a trade union and thus being subject to Article 28.1 of the Spanish Constitution ${ }^{8}$ and the Organic Law on Trade Union Freedom. Under the legal basis of the scheme of Article 22 of the Spanish Constitution, which recognises the right of association, and the Organic Law

\footnotetext{
${ }^{7}$ According to Article 28.2 of the Spanish Constitution, "[t] he right of workers to strike in defence of their interests is recognised. The law governing the exercise of this right shall establish the safeguards necessary to ensure the maintenance of essential public services".

${ }^{8}$ According to Article 28.1 of the Spanish Constitution, "[a]11 have the right to freely join a trade union. The law may restrict or except the exercise of this right in the Armed Forces or Institutes or other bodies subject to military discipline, and shall lay down the special conditions of its exercise by civil servants. Trade union freedom includes the right to set up trade unions and to join the union of one's choice, as well as the right of trade unions to form confederations and to found international trade union organizations, or to become members thereof. No one may be compelled to join a trade union".
} 
on the Right of Association (Ley Orgánica 1/2002, de 22 de marzo, reguladora del Derecho de Asociación ${ }^{9}$ ), they are also granted the right of being members of a professional organisation. This is confirmed by the wording of Article 3.2 LETA, which - with regard to professional interests agreements (acuerdos de interés profesional) - states that "any clause in the individual contract of an economically dependent self-employed worker who is affiliated to a trade union or a self-employed workers association that may apply to such worker for having entered into such contract, will be null and void if it infringes the terms of the professional interest agreement entered into by such trade union or association".

The right to strike has not been excluded as regards economically dependent self-employed workers (Moreno Vida 2017, 647). ${ }^{10}$ The right to collective bargaining has also been extended to that group (Countouris, De Stefano 2019, 27). The Spanish legislator has done so by establishing specific professional interests agreements, which have already been mentioned above.

According to Article 3.2 LETA, professional interest agreements are the source of the professional regime of economically dependent self-employed workers. They are concluded between the associations or unions that represent economically dependent self-employed workers and the companies for which they carry out their activity, and they may establish the conditions on the way, time and place of the execution of such activity, as well as other general contracting conditions (Article 13.1 LETA). The analysis should be intended to highlight problems arising from the provision in the light of which: "Professional interests agreements shall be concluded under the provisions of the Civil Code. The personal effectiveness of said agreements shall be limited to the signatory parties and, if appropriate, to those affiliated to self-employed workers associations or signatory unions that have expressly given their consent to do so" (Article 13.4 LETA). As rightly stated by J.M. Gómez Muñoz $(2017,140)$, we are dealing here with a hybrid negotiation procedure characterised by the convergence of labour, civil, and trade union regulations. The author has pointed out that the Spanish Civil Code does not regulate any procedure of entering into agreements, so one might deduce that professional interests agreements shall be concluded under the "clauses of formation and defects of willingness to contract", what is in "contraposition with the rules on representativeness and legitimacy to negotiate collective agreements, which partially apply to these agreements".

As regards the personal effectiveness of professional interests agreements referred to in Article 13.4 LETA, the problem seems to be even more complicated, because it turns out that in the case of certain employers only the workers who are members of the trade unions that have signed the agreement beforehand will be

${ }^{9}$ Boletín Oficial del Estado, 26 March 2002, no. 73.

${ }^{10}$ It should be noted, however, that a contrary view is expressed by Countouris, De Stefano $(2019,27)$, according to whom the right to strike is reserved only to employees in Spain. 
entitled to enter into agreements. Such a consequence is described as the emergence of the constitutionally banned closed-shop clause. This means that the Spanish legislator has not paid enough attention to the erga omnes effectiveness of the collective agreements, even if professional interests agreements, formally speaking, are a different legal figure from them. Moreover, in the light of Article 21.1 LETA, associations registered in the National Register of Professional Associations of Self-Employed Workers (Registro Estatal de Asociaciones Profesionales de Trabajadores Autónomos), which demonstrate sufficient implementation at the national level (suficiente implantación en el ámbito nacional) shall be considered as representative professional associations of self-employed workers at the state level. The point here is quite simple. "Sufficient implementation at the national level" criterion has been created as the sole indicator of recognising the representativeness of professional associations of self-employed workers. LETA neither establishes minimum thresholds nor determines who is legitimate to enter into professional interests agreements. Thus, the negotiation of professional interests agreements turns out to be an indicator of representativeness. Besides, trade unions can enter into professional interests agreements without being obliged to demonstrate any given representativeness. In contrast, it is worth noting that "in the employee trade union sphere", only sufficiently representative trade unions can enter into agreements. Given this, J.M. Gómez Muñoz concludes that "this regulation model can generate clearly discriminatory practices among groups"”11 (Gómez Muñoz 2017, 140-141).

It should be further noted that the analysis of the extant literature reveals that in Spain, there are only 10,000 workers registered as economically dependent self-employed persons, what - as has been pointed out by A. Todolí-Signes (2019, 258 ) - represents less than $0.33 \%$ of all self-employed workers and less than $0.05 \%$ of the total number of workers in that country. Besides, even if economically dependent self-employed workers are granted the right to bargain collectively, collective bargaining "is extremely limited in practice" and takes place only at the company level (Countouris, De Stefano 2019, 40).

\section{CONCLUSIONS FOR POLAND}

The aim of this paper was to evaluate collective labour rights of both "classic" self-employed persons and economically dependent self-employed workers under Spanish LETA. Such analysis was intended to discover whether the Polish legislator would be able to draw a lesson from Spanish regulations.

${ }^{11}$ In Spain, professional interests agreements with effects on labour and limited effectiveness, which are binding for trade unions put self-employed workers unions in a less favourable position as regards "guaranteed rights than the rest of trade unions made up by employees" (Gómez Muñoz 2017, 140-141). 
Article 19 LETA establishes professional and collective rights of selfemployed persons under the "Joint regime", but what is really interesting are the main asymmetries in rights between "classic" self-employed persons and economically dependent self-employed workers. Firstly, the findings presented indicate that the right to strike has been denied to "classic" self-employed workers, however, it has not been excluded in relation to economically dependent selfemployed workers. Secondly, the essay explains that among all self-employed workers, only economically dependent self-employed workers have been granted the right to bargain collectively. However - in addition to the above-mentioned problems of "effectiveness" and "representativeness" - it seems proved by the presented data that in practice, collective bargaining is limited due to the facts that it takes place only at the enterprise level, and that the number of economically dependent self-employed workers is very low.

In the light of the conclusion that collective labour rights under LETA could be better protected (especially as regards "classic" self-employed persons), it is worth trying to draw conclusions for Poland. Taking into account Spanish regulations, it is clear that the protection in question is much more modest than that which is available in our country. Since 1 January 2019, self-employed persons registered as sole traders who do not employ other people have been granted the right to coalition, which encompasses both the right to create and join trade unions and to create organisations of self-employed persons. Moreover, self-employed persons and union organisations associating them have been given the right to negotiate and conclude collective labour agreements that set certain minimum protection standards for all self-employed workers falling within their scope of application. The lack of any criteria that would enable a diversification of the scope of collective rights granted to self-employed persons is subject to criticism (Duraj 2020,75). As rightly stated by $T$. Duraj, these persons, by creating a trade union or joining an already existing organisation enjoy the same privileges, regardless of whether they are permanently associated with the service provider or only occasionally render him/her services. The author postulates that in some areas the legislator shall differentiate the scope of protection, referring, for example, to the criterion of economic dependence, in the likeness of the Spanish LETA (Duraj 2020, 75). It seems that this criterion could indeed be used to differentiate the scope of protection. However, following the example of LETA, it would be necessary to eliminate the above-mentioned shortcomings resulting from this statute.

\section{BIBLIOGRAPHY}

Apilluelo Martín, Margarita. 2018. "Ámbito subjetivo de aplicación”. In Tratado del Trabajo Autónomo. Edited by Guillermo L. Barrios Baudor. 35-62. Navarra: Thomson Reuters Aranzadi. 
Countouris, Nicola. Valerio De Stefano. 2019. New Trade Union Strategies for New Forms of Employment. Brussels: ETUC.

Duraj, Tomasz. 2020. "Prawo koalicji osób pracujących zarobkowo na własny rachunek po nowelizacji prawa związkowego - szanse i zagrożenia". Studia z Zakresu Prawa Pracy i Polityki Społecznej 27(2): 67-77. https://doi.org/10.4467/25444654SPP.20.007.11945

Ginès i Fabrellas, Anna. 2020. "Atypical Work as Flexible Work: The Rise of Labour Instability in the Spanish Labour Market”. Z Problematyki Prawa Pracy i Polityki Socjalnej 1(18): 61-87. https://doi.org/10.31261/zpppips.2020.18.04

Gómez, Muñoz. José Manuel. 2017. "Re-addressing Self-employment: Spain and the New Entrepreneurship". In Core and Contingent Work in the European Union: A Comparative Analysis. Edited by Edoardo Ales, Olaf Deinert, Jeff Kenner. 129-152. Oxford: Hart Publishing.

Martín-Artiles, Antonio. Alejandro Godino. Oscar Molina. 2019. "Spain: The Trend to Professionals' Precarization". In The Challenges of Self-Employment in Europe: Status, Social Protection and Collective Representation. Edited by Renata Semenza, François Pichault. 116-122. Cheltenham, UK-Northampton, MA, USA: Edward Elgar Publishing.

Moreno Vida, Nieves. 2017. "Los instrumentos de «presión colectiva» y su singularidad en el trabajo autónomo". In El trabajo autónomo en el marco del Derecho del Trabajo y de la Seguridad Social: Estudio de su régimen jurídico. Actualizado a la Ley 6/2017, de 24 de octubre de Reformas Urgentes del Trabajo Autónomo. Edited by José Luis Monereo Pérez, Francisco Vila Tierno. 633-651. Granada: Editorial Comares.

Pérez Agulla, Sira. 2016. “Trabajo Autónomo. Régimen Jurídico de la Prestación de Servicios Tras las Reformas Legislativas de 2015”. In Colección Derecho del Trabajo y Seguridad Social. Edited by Yolanda Sánchez-Urán Azaña. 1-177. Lisboa: Editorial Juruá.

Todolí-Signes, Adrián. 2019. "Workers, the Self-employed and TRADEs: Conceptualisation and Collective Rights in Spain”. European Labour Law Journal 10(3): 254-270. 